\title{
Effect of Different Holding Solutions on Postharvest Life of Iris (Iris orientalis Mill.)
}

\author{
Mallika Thakur*, B.P. Sharma and Tamanna Verma
}

Department of Floriculture and Landscape Architecture, Dr YS Parmar University of Horticulture and Forestry, Nauni, Solan 173230 Himachal Pradesh, India

*Corresponding author

\section{A B S T R A C T}

\section{Keywords \\ Iris orientalis Mill., holding solution, Vase life \\ Article Info \\ Accepted: \\ 17 April 2019 \\ Available Online: \\ 10 May 2019}

\begin{abstract}
The investigation entitled, "Effect of different holding solutions on postharvest life of Iris (Iris orientalis Mill.)" was carried out at the experimental farm and laboratory of Department of Floriculture and Landscape Architecture, Dr Yashwant Singh Parmar University of Horticulture and Forestry, Nauni, Solan, in the year 2018. Experiment was laid out in Completely Randomized Design with 10 treatments and 3 replications. Holding cut spikes in solution comprising of Sucrose $(3 \%)+8$-HQC $(300 \mathrm{ppm})+\mathrm{BA}(150 \mathrm{ppm})$ resulted in best treatment for most of the postharvest parameters such as amount of solution consumed (116.58 ml), appearance of cut bloom (4.62), days taken for opening of floret (2.40), floret diameter $(14.94 \mathrm{~cm})$, vase life (15.87 days) and minimum per cent weight change/loss $23.13 \%$ ) of the cut spikes with $100 \%$ bud opening.
\end{abstract}

\section{Introduction}

Iris orientalis Mill. is amongst species of family Iridaceae in the genus of Iris. It falls in the subgenus of Limniris and in series Spuriae. It is a rhizomatous perennial plant, native to Asia Minor, bearing beardless white flowers with a yellow mark or blotch. It is very hardy and has been known to naturalize in various countries. It is widely cultivated as an ornamental plant in temperate regions. Being a member of an ethylene insensitive family, it has a considerable potential to become a prized ornamental cut flower (van Doorn and Woltering, 2008; Zhong and Ciafre, 2011). The majority of the genus belongs to the rhizomatous group while only a few to the bulbous types whereas only latter types are grown commercially for cut flower use when grown under greenhouse or in the open. The international trade for cut flowers has greatly been expanded in recent years. Hence, there is an increased interest in postharvest biology and biochemistry of cut flowers. Most cut flowers have limited vase life owing to their moisture content, delicacy and tenderness. Hence, flowers and ornamentals are most susceptible to mechanical, physical damages and microbial infections during and after harvest. There are several pre and postharvest factors which affects the longevity of cut flowers. The 
important factors, which affect postharvest quality and longevity of cut flowers during postharvest handling are time of harvest, mode of harvesting, temperature, humidity, light, ethylene production, flower sensitivity and micro-organisms. In order to preserve the best quality flowers after harvest and making them tolerant to fluctuation in the environmental conditions, treatments with floral preservatives have been recommended. Commonly most preservative solutions consist of carbohydrates, germicides, ethylene inhibitors, growth regulators and some mineral compounds. Extension of vase life and improvement of keeping quality of cut flowers are important areas of research in the postharvest sector of floriculture industry. There is only scanty information available on postharvest handling of cut iris. Hence preservation of best quality flowers and enhancement of postharvest life of cut iris is an important area of research in the field of floriculture. Therefore present study has been undertaken with the objective to find out the best holding solution for Iris (Iris orientalis Mill).

\section{Materials and Methods}

The present investigation was carried out in the laboratory of Department of Floriculture and Landscape Architecture, Dr YS Parmar University of Horticulture and Forestry, Nauni, Solan during 2018. Uniform, healthy and disease free rhizomes were selected and used further for the present study. Planting was done in beds of convenient length with a width of $1.2 \mathrm{~m}$ raised about $15 \mathrm{~cm}$ from ground level at a spacing of $20 \times 20 \mathrm{~cm}$. The cut spikes of uniform size were harvested in the morning hours (7-8 am) with the help of a sharp secateur. After harvesting, these spikes were immediately placed in a bucket containing water. The stage of harvesting for cut iris was 'pencil tip'. After harvesting, cut spikes were taken to the laboratory in the department of Floriculture and Landscape Architecture for conducting the experiment. The lower leaves from cut spikes were removed retaining 3-4 upper leaves. A slanting cut was given at the base of each cut spike in such a manner that the final cut spike length remained $55 \mathrm{~cm}$.

\section{Results and Discussion}

Cut spikes consumed maximum amount of solution $(116.58 \mathrm{ml})$ when held in $\mathrm{T}_{7}$ comprising of Sucrose $(3 \%)+8$-HQC (300 $\mathrm{ppm})+\mathrm{BA}(150 \mathrm{ppm})$. However in $\mathrm{T}_{1}$ (distilled water) cut spikes consumed minimum amount of holding solution (Table 1). It was observed during investigation that cut spikes put in the various holding solutions consumed significantly larger amount of solution over spikes kept in the control (distilled water). The results are in consent with the findings of Marousky (1972) who confirmed that 8-HQC inhibited stem plugging by reducing the $\mathrm{pH}$ of solution and thereby increased the conductivity of stems hence, cut flowers absorbed more amount of solution. Similar results were reported by Dastagiri (1013) in chincherinchee and Murry (2014) while working in tuberose.

The cut flowers retain maximum freshness and colour with the highest score of 4.62 when held in $\mathrm{T}_{7}$ i.e. Sucrose $3 \%+8$-HQC $(300 \mathrm{ppm})+$ BA $(150 \mathrm{ppm})$. On contrary, cut flowers when held in distilled water $\left(\mathrm{T}_{1}\right)$ recorded poor appearance with minimum score of 3.70. All holding solutions tested in this experiment resulted in enhanced overall appearance of flowers over control. However, the best appearance was registered in case of $\mathrm{T}_{7}$ i.e. Sucrose $(3 \%)+8$-HQC $(300 \mathrm{ppm})+$ BA $(150 \mathrm{ppm})$. This might be due to the fact that sucrose supplied the substrate for continuous respiration (Morousky, 1971), maintained mitochondrial structure and function whereas 8-HQC prevented vascular 
blockage, cause stomatal closure and improved water balance. This may also be attributed to presence of BA in solution which has increased quantum yield of photosynthesis in the leaves and helped in retaining natural flower colour for longer duration. This may be because of the fact that BA delays senescence by improving the membrane stability of cut flowers (Guo et al., 1997). The result got support from the findings of Manikrao (2007) in alstroemeria, Dastagiri (2013) in chincherinchee, Murry (2014) in tuberose and Chunne (2015) in hydrangea.

The cut spikes took minimum days for opening i.e. 2.40 days when held in $\mathrm{T}_{7}$ namely Sucrose $3 \%+8$-HQC (300ppm) + BA (150 ppm). On contrary, the cut spikes held in distilled water $\left(\mathrm{T}_{1}\right)$ took maximum days (4.33 days) for opening of first floret. It was observed that florets in all the holding solutions opened earlier as compared to control (distilled water). Particularly in the presence of lower levels of BA, florets took maximum number of days to open when held in distilled water. Besides sugars and biocides, cytokinins also stimulates bud opening via auxin and proton secretion. This proton secretion acidifies the petal cell walls which allow expansion to occur (Bhattacharjee, 1999). The results got support from finding of Dastagiri (2013) in chincherinchee.

Largest floret diameter (14.94) was recorded in cut spikes treated with $\mathrm{T}_{7}$ i.e. Sucrose $3 \%$ + 8-HQC (300ppm) + BA (150 ppm). Minimum floret diameter $(13.43 \mathrm{~cm})$ was recorded in those cut spikes held in distilled water $\left(T_{1}\right)$. This increase in flower diameter may be due to the ability of cytokinins in cell enlargement which ultimately increased the flower diameter. It is well documented that the accumulation of carbohydrates and more water uptake had direct effect on increase in the cell volume. The petal cell of untreated flowers with poor water uptake might have been flaccid and deplasmolysed, leading to reduced size of cells and that of petals. Moreover, sucrose availability might have facilitated higher rate of respiration necessary for cell division, cell enlargement and providing of ' $\mathrm{C}$ ' skeleton for the tissue structure contributing to petal expansion and formation of cell constituents and, thus, caused increased flower diameter (Ho and Nichols, 1977) in rose. Further addition of BA in solution has helped to enhance longevity and delayed catabolic activities which increased the flower quality and resulted in availability of more substrates to the flower. These results also got support from findings of Lukaszewska (1995) in rose, De and Bhattacharjee (1999) in rose cv. 'Super Star', Bhatia (2000) in carnation cvs. 'Impala' and 'Purple Choppin', Singh et al., (2000) and Nagarajuna et al., (2002) in tuberose, Dastagiri (2013) in chincherinchee and Murry (2014) in tuberose.

It is clear from data presented in Table 1 that cut spikes when held in holding solution containing Sucrose $3 \%+8$-HQC (300ppm) + BA $(150 \mathrm{ppm})$ i.e. $\mathrm{T}_{7}$ resulted the longest vase life (15.87 days) whereas, minimum vase life (9.93 days) was recorded in those cut spikes held in distilled water $\left(\mathrm{T}_{1}\right)$. During the investigation, it was observed that cut spikes kept in different holding solutions exhibited longer vase life as compared to those held in distilled water (control). This may be attributed to the reduced stem conductivity. As there are many chances of growth of different micro-organisms in distilled water which may check/reduce the proper conductivity of water (Accati et al., 1981) and results in early senescence. The superiority of 8-HQC in enhancing various postharvest parameters has also been verified in present studies. The main cause of decline in solution uptake is microbial growth in vase water that 
caused reduction in absorption of solutions (Halevy and Mayak, 1981) besides 8-HQC has been suggested for prolonging vase life of cut flowers by inhibiting bacterial growth and stem blockage. The results obtained got support from the studies of Manikrao (2007) in alstroemeria, Kim and Lee (2010) in iris and Chunne (2015) in hydrangea.

Table.1 Effect of different holding solutions on postharvest life of Iris (Iris orientalis Mill.)

\begin{tabular}{|c|c|c|c|c|c|c|c|}
\hline Treatment & Holding solutions & $\begin{array}{l}\text { Amount of } \\
\text { vase solution } \\
\text { consumed } \\
\text { (ml) }\end{array}$ & $\begin{array}{c}\text { Appearance } \\
\text { (Score out of } \\
5 \text { ) }\end{array}$ & $\begin{array}{c}\text { Days taken } \\
\text { for opening } \\
\text { of floret } \\
\text { (days) }\end{array}$ & $\begin{array}{c}\text { Floret } \\
\text { diameter } \\
\text { (cm) }\end{array}$ & $\begin{array}{l}\text { Vase } \\
\text { life } \\
\text { (days) }\end{array}$ & $\begin{array}{c}\text { Per cent } \\
\text { weight } \\
\text { change } \\
\text { (loss) }\end{array}$ \\
\hline $\mathbf{T}_{1}$ & Distilled Water (control) & 65.47 & 3.70 & 4.33 & 13.43 & 9.93 & 47.42 \\
\hline $\mathbf{T}_{2}$ & Sucrose $3 \%+8-\mathrm{HQC}(200 \mathrm{ppm})+\mathrm{BA}(50 \mathrm{ppm})$ & 70.48 & 3.78 & 3.27 & 13.83 & 10.87 & 39.13 \\
\hline $\mathbf{T}_{\mathbf{3}}$ & Sucrose $3 \%+8$-HQC (200 ppm) + BA (100 ppm) & 77.53 & 3.86 & 3.13 & 13.90 & 11.67 & 39.30 \\
\hline $\mathbf{T}_{4}$ & Sucrose $3 \%+8-\mathrm{HQC}(200 \mathrm{ppm})+\mathrm{BA}(150 \mathrm{ppm})$ & 82.35 & 3.90 & 2.93 & 13.93 & 13.07 & 40.40 \\
\hline $\mathbf{T}_{5}$ & Sucrose $3 \%+8-\mathrm{HQC}(300 \mathrm{ppm})+\mathrm{BA}(50 \mathrm{ppm})$ & 92.21 & 3.95 & 2.60 & 14.08 & 13.67 & 34.72 \\
\hline $\mathbf{T}_{6}$ & Sucrose $3 \%+8-\mathrm{HQC}(300 \mathrm{ppm})+\mathrm{BA}(100 \mathrm{ppm})$ & 103.22 & 4.38 & 2.53 & 14.29 & 14.27 & 32.58 \\
\hline $\mathbf{T}_{7}$ & Sucrose $3 \%+8-\mathrm{HQC}(300 \mathrm{ppm})+\mathrm{BA}(150 \mathrm{ppm})$ & 116.58 & 4.62 & 2.40 & 14.94 & 15.87 & 23.13 \\
\hline $\mathbf{T}_{8}$ & Sucrose $3 \%+8-\mathrm{HQC}(400 \mathrm{ppm})+\mathrm{BA}(50 \mathrm{ppm})$ & 105.27 & 4.51 & 2.67 & 14.38 & 14.87 & 25.21 \\
\hline $\mathbf{T}_{9}$ & Sucrose $3 \%+8-\mathrm{HQC}(400 \mathrm{ppm})+\mathrm{BA}(100 \mathrm{ppm})$ & 92.24 & 4.23 & 2.53 & 14.26 & 14.13 & 27.62 \\
\hline $\mathbf{T}_{10}$ & Sucrose $3 \%+8-\mathrm{HQC}(400 \mathrm{ppm})+\mathrm{BA}(150 \mathrm{ppm})$ & 86.48 & 4.11 & 2.47 & 14.12 & 13.80 & 29.36 \\
\hline $\mathrm{CD}_{0.05}$ & & 2.70 & 0.04 & 0.18 & 0.09 & 0.31 & 0.92 \\
\hline
\end{tabular}

It is evident from Table 1 that minimum weight loss $(23.13 \%)$ was observed in cut spikes when held in treatment $T_{7}$ i.e. Sucrose $3 \%+8$-HQC (300ppm) + BA (150 ppm) whereas, cut spikes placed in holding solution containing distilled water $\left(\mathrm{T}_{1}\right)$ recorded maximum weight loss $(47.42 \%)$ and it was found to be significantly higher than other treatments. The above findings might be due to the effect of sucrose and 8-HQC in inducing the higher uptake of vase solution, less water loss and decrease in the aperture size of leaf stomata. Further, 8-HQC enhanced water uptake by avoiding blockage of xylem tissues which resulted in higher fresh weight. The results are in conformity with the findings of Murry (2014) in tuberose and Chunne (2015) in hydrangea. Keeping in view the above findings, it can be concluded that holding solution comprising of Sucrose $(3 \%)+8$-HQC $(300 \mathrm{ppm})+\mathrm{BA}(150 \mathrm{ppm})$ improved the overall longevity of cut iris.

References
Accati E, Mayak S and Gentile IA. 1981. The role of bacterial metabolites in affecting water uptake by carnation flowers. Acta Horticulturae 113:153-158.

Bhatia S. 2000. Studies of Pulsing and Storage of Carnation Cut Flowers. MSc Thesis. Department of Floriculture and Landscape Architecture, Dr YS Parmar University of Horticulture and Forestry, Solan. $47 \mathrm{p}$.

Chunne T. 2015. Studies on Postharvest Handling of Hydrangea (Hydrangea macrophylla Thunb.) as Influenced by Pre-harvest Fertilization. MSc Thesis. Department of Floriculture and Landscape Architecture, Dr YS Parmar University of Horticulture and Forestry, Solan. 67p.

Dastagiri D. 2013. Studies on Postharvest Handling of Chincherinchee (Ornithogalum thyrsoides Jacq.). MSc Thesis. Department of Floriculture and 
Landscape Architecture, Dr YS Parmar University of Horticulture and Forestry, Solan. 60p.

De LC and Bhattacharjee SK. 1999. Effect of chemicals for tight bud opening of rose cv. 'Super Star' at different stages of maturity. Annals of Agricultural Research 20:206-211.

Doorn WG and Woltering EJ. 2008. Physiology and molecular biology of petal senescence. Journal of Experimental Botany 59:453-480.

Guo WM, Zhang ZH and Fang WM. 1997. Effect of 6-BA on physiological response of cut chrysanthemum during vase periods. Acta Horticulturae Sinica 24:364-368.

Halevy AH and Mayak S. 1981. Senescence and postharvest physiology of cut flowers. Horticultural Review 32:59143.

Ho LC and Nichols R. 1997. Translocation of $14 \mathrm{C}$ sucrose in relation to change in carbohydrate content in rose corollas cut at different stages of development. Annals of Botany 41:227-242.

Kim YA and Lee JS. 2010. Effect of cycloheximide and holding solution on vase life of cut 'Blue Magic' iris flowers according to the flower development and opening stages. Korean Journal of Horticultural Science and Technology 28:790-795.

Lukaszewska AJ. 1995. Distribution of sugars in tulip flower parts as affected by Ethrel and $\mathrm{GA}_{3}$. Acta Horticulturae 405:351-355.
Manikrao DR. 2007. Studies on Possible Alternatives of Silver Thiosulphate in Postharvest Handling of Alstroemeria and Carnation Cut Flowers. $\mathrm{PhD}$ Thesis. Department of Floriculture and Landscape Architecture, Dr YS Parmar University of Horticulture and Forestry, Solan. $119 \mathrm{p}$.

Marousky FJ. 1971. Inhibition of vascular blockage and moisture retention in cut roses induced by $\mathrm{pH}, \quad 8$ hydroxyquinoline citrate and sucrose. Journal of the American Society for Horticultural Science 96:38-41.

Marousky FG. 1972. Water relations, effect of floral preservatives on bud opening and keeping quality of cut flowers. HortScience 7:114-117.

Murry NA. 2014. Postharvest Handling of Tuberose (Polianthes tuberosa Linn.) cv. 'Double'. MSc Thesis. Department of Floriculture and Landscape Architecture, Dr YS Parmar University of Horticulture and Forestry, Solan. $64 p$.

Nagarjuna HT, Narayanagowda JV and Nagaraja GS. 2002. Effect of pulsing with sucrose on vase life of tuberose cv. 'Double'. Crop Research Hisar 23:349353.

Zhong Y and Ciafre C. 2011. Role of ABA in ethylene-independent Iris flower senescence. 2011 International Conference on Food Engineering and Biotechnology IPCBEE vol.9, IACSIT Press, Singapore.

\section{How to cite this article:}

Mallika Thakur, B.P. Sharma and Tamanna Verma. 2019. Effect of Different Holding Solutions on Postharvest Life of Iris (Iris orientalis Mill.). Int.J.Curr.Microbiol.App.Sci. 8(05): 2125-2129. doi: https://doi.org/10.20546/ijcmas.2019.805.248 